\title{
M-Cresyl Acetate
}

National Cancer Institute

\section{Source}

National Cancer Institute. m-CresylAcetate. NCI Thesaurus. Code C87635.

The acetic acid ester of metacresol, an agent with antiseptic and analgesic properties. mCresyl acetate is used in an otic solution to treat bacterial and fung al infections of the outer ear, and in endodontic procedures. 